\title{
PRODUKSI KITINASE DAN KITIN DEASETILASE DARI Vibrio harveyi
}

\author{
Suyuti Nasran, Farida Ariyani, dan Ninoek Indriati”)
}

\begin{abstract}
ABSTRAK
Penelitian untuk mengetahui potensi Vibrio harveyi sebagai penghasil kitinase dan kitin deasetilase telah dilakukan. Untuk mengetahui kondisi yang diperlukan untuk memproduksi enzim, telah dilakukan percobaan produksi enzim pada $\mathrm{pH} 6,7$, dan 8 dengan 3 tingkatan suhu inkubasi yaitu suhu kamar $\left(28-31^{\circ} \mathrm{C}\right), 37^{\circ} \mathrm{C}$, dan $47^{\circ} \mathrm{C}$ selama 5 hari. Hasil penelitian menunjukkan bahwa Vibrio harveyi dapat memproduksi enzim kitinase dan kitin deasetilase seperti ditunjukkan dari hasil uji daya kitinolitik, walaupun aktivitas enzim yang diperoleh masih rendah. Sama halnya dengan perkembangan jumlah bakteri selama masa produksi enzim, aktivitas enzim kitinase dipengaruhi oleh suhu inkubasi, tetapi tidak oleh $\mathrm{pH}$ media. Terdapat perbedaan aktivitas enzim pada inkubasi $37^{\circ} \mathrm{C}$ selama 5 hari yang mencapai rata-rata $10,82 \times 10^{-6} \mathrm{u} / \mathrm{ml}$ dibandingkan dengan pada suhu $47^{\circ} \mathrm{C}$ yang hanya mempunyai aktivitas sebesar $3,56 \times 10^{-6} \mathrm{u} / \mathrm{ml}$. Sebaliknya, aktivitas enzim kitin deasetilase justru lebih dipengaruhi oleh $\mathrm{pH}$ media daripada suhu dan lama inkubasinya. Aktivitas kitin deasetilase rata-rata pada $\mathrm{pH} 6,7$, dan 8 berturut-turut adalah $5,6 \times$ $10^{-5} \mathrm{u} / \mathrm{ml} ; 3,8 \times 10^{-5} \mathrm{u} / \mathrm{ml}$, dan $6,0 \times 10^{-5} \mathrm{u} / \mathrm{ml}$.
\end{abstract}

\section{ABSTRACT: Production of chitinase and chitin deacetylase from Vibrio harveyi. By: Suyuti Nasran, Farida Ariyani and Ninoek Indriati}

Research aimed at finding the potentiality of Vibrio harveyi in producing chitinase as well as chitin deacetylase has been carried out. To find out the appropriate condition for producing the enzymes, an experiment on enzyme production was conducted using three levels of pH, i.e. 6,7 , and 8 and three kinds of incubation temperatures, i.e. ambient $\left(28-31^{\circ} \mathrm{C}\right), 37^{\circ} \mathrm{C}$, and $47^{\circ} \mathrm{C}$ for 5 days. Research result revealed that Vibrio harveyi could produce chitinase and chitin deacetylase, though the enzyme activities of both enzymes were still low. Similar to the changes of bacterial count during the production of enzymes, the activity of chitinase was affected by incubation temperature, but was not by the $\mathrm{pH}$ of the growing media. There was a significant difference between the average enzyme activities, which was $10.82 \times 10^{-6} \mathrm{u} / \mathrm{ml}$ at incubation temperature of $37^{\circ} \mathrm{C}$, compared to only $3.56 \times 10^{-6} \mathrm{u} / \mathrm{ml}$ at $47^{\circ} \mathrm{C}$. On the contrary, the activity of chitin deacetylase was affected by $\mathrm{pH}$, not by the temperature and time of incubation. The average activities at $\mathrm{pH} 6,7$, and 8 were $5.6 \times 10^{-5} \mathrm{u} / \mathrm{ml} ; 3.8 \times 10^{-5} \mathrm{u} / \mathrm{ml}$, and $6.0 \times 10^{-5} \mathrm{u} / \mathrm{ml}$ respectively.

KEYWORDS: chitinase, chitin deacetylase, Vibrio harveyi

\section{PENDAHULUAN}

Kitinase dan kitin deasetilase adalah enzim yang aktif mengkatalisis degradasi kitin. Kitinase dapat menghidrolisis kitin secara acak pada ikatan glikosidiknya, sedang kitin deasetilase menghidrolisis kitin menjadi produk yang mempunyai daya guna yang lebih tinggi seperti kitosan.

Proses konversi kitin secara kimiawi dapat dilakukan menggunakan larutan $\mathrm{NaOH}$ pada kadar dan suhu tinggi. Teknologinya relatif mudah, tetapi mutu kitosan yang dihasilkan dengan cara ini kurang seragam, meskipun telah dibantu dengan pengadukan (Saleh et al., 1994). Hal ini lebih disebabkan karena hidrolisis secara kimiawi bersifat acak/tidak spesifik pada ikatan/gugus tertentu seperti hidrolisis oleh enzim.
Teknologi alternatif adalah menggunakan enzim kitinase dan kitin deasetilase. Kedua jenis enzim ini terdapat secara ekstraseluler dalam lapisan lendir lambung dan usus serta darah beberapa jenis ikan. Bakteri pembentuk kitinase dan kitobiase dalam saluran pencernaan ikan cod ternyata sangat mirip dengan Vibrio campbellii dan Vibrio anguillarum (Lindsay dan Gooday, 1985).

Banyak jenis mikroorganisme dapat memproduksi enzim pendegradasi kitin dan kitosan, baik bakteri seperti Pseudomonas aeruginosa (Wang dan Chang, 1997). Streptococcus lydicus (Crawford dan Mahadevan, 1997), Bacillus circulans (Alam et al., 1996), Bacillus megaterium (Pelletier et al.,1990), Streptomyces spp. (Boucher et al., 1992), dan Vibrio alginolyticus (Ohishi et al., 1996). Beberapa jenis jamur seperti Aspergillus carneus (Sherief et al., 1991),

Peneliti pada Pusat Riset Pengolahan Produk dan Sosial Ekonomi Kelautan dan Perikanan 
Aspergillus nidulans (Alfonso et al.,1995; Reves et al., 1995), Mucor rouxii (Bouriotis et al., 1993; Martinou et al., 1995; Kafetzoupoulos et al., 1994) Absidia coerulea (Gao et al., 1995), dan Trichoderma reesei juga menghasilkan enzim serupa (Morikawa et al., 1998).

Beberapa strain Vibrio harveyi diketahui dapat menghasilkan enzim kitinase dan kitin deasetilase (Kirchman et al., 1997). Kitinase yang dihasilkan oleh mikroorganisme memberikan prospek yang lebih baik dibandingkan kitinase dari sumber lain karena kemudahannya dimanipulasi pada level molekuler (Alam et al., 1996). Svitil et al., (1997) telah membuktikan bahwa $V$. harveyi BB7 menghasilkan beberapa jenis kitinase dengan bobot molekul yang berbeda-beda, yang bervariasi dari $42-130 \mathrm{kDa}$, sesuai dengan jenis substrat sebagai sumber kitin. Vibrio alginolyticus $\mathrm{H}-8$ menghasilkan dua jenis kitinase yaitu $\mathrm{C} 1$ dan $\mathrm{C} 3$ dengan bobot molekul masing-masing 81 dan $68 \mathrm{kDa}$ (Ohishi et al., 1996). Bacillus circulans WL-12 menghasilkan paling kurang 6 jenis kitinase yang berbeda-beda dalam aktivitas enzimnya (Alam et al., 1996)

Beragamnya kemampuan bakteri menghasilkan berbagai jenis kitinase dan enzim pendegradasi kitin lainnya kemungkinan merupakan upaya penyesuaian terhadap beragamnya jenis, tipe, dan struktur kitin yang tersedia di alam.

Untuk mengetahui potensi $V$. harveyi uji sebagai penghasil kitinase dan kitin deasetilase, sekaligus untuk mendapatkan kondisi yang tepat untuk produksi, dilakukan percobaan produksi enzim pada $\mathrm{pH}$, suhu, dan waktu produksi yang berbeda.

\section{BAHAN DAN METODE}

Kitin yang digunakan dalam percobaan ini adalah kitin rajungan buatan Sigma Chemical Co. St. Louis, MO, USA, sedangkan kultur murni Vibrio harveyi uji diperoleh dari Balai Besar Penelitan Budidaya Laut Gondol, Bali

\section{Pembuatan Koloidal Kitin (Sebagai Substrat dalam Pengukuran Aktivitas Kitinase)}

Koloidal kitin dibuat dengan melarutkan $10 \mathrm{~g}$ kitin dalam $200 \mathrm{ml} \mathrm{HCl}$ pekat, kemudian didiamkan semalam pada suhu $4^{\circ} \mathrm{C}$, dan disaring menggunakan glass-wool. Setelah ditambah $100 \mathrm{ml}$ akuades dingin dan dinetralkan dengan $\mathrm{NaOH} 12 \mathrm{~N}( \pm 200 \mathrm{ml})$, larutan kemudian disentrifus dengan kecepatan $8.000 \mathrm{rpm}$ selama 20 menit pada suhu $4^{\circ} \mathrm{C}$. Setelah supernatan dibuang, endapan ditambah akuades dingin, dan diaduk untuk melarutkan sisa garam kemudian disentrifus kembali dengan kecepatan 8.000 rpm selama 20 menit pada suhu $4^{\circ} \mathrm{C}$ (Arnold \& Solomon, 1986).

\section{Pembuatan Glikol Kitin (Sebagai Substrat dalam Pengukuran Aktivitas Kitin Deasetilase)}

Glikol kitin dibuat dengan melarutkan $1 \mathrm{~g}$ glikol kitosan (Sigma) dalam $20 \mathrm{ml}$ asam asetat 10\%, kemudian dibiarkan selama 24 jam pada suhu ruang. Setelah itu ditambahkan $100 \mathrm{ml}$ metanol secara perlahan-lahan, kemudian disaring dengan kertas Whatman No.41 menggunakan pompa vakum. Filtrat yang diperoleh ditambah $1,5 \mathrm{ml}$ asetat anhidrid sambil diaduk pelan-pelan, dan dibiarkan 10 menit pada suhu ruang. Pada saat terbentuk gel, ditambah $150 \mathrm{ml}$ metanol dan dihomogenisasikan, selanjutnya disentrifus dengan kecepatan 7.000 rpm pada suhu $4^{\circ} \mathrm{C}$ selama 15 menit. Endapan yang diperoleh ditambah dengan 100-150 ml metanol, kemudian dihomogenisasikan kembali sebelum disentrifus ulang dengan cara yang sama seperti sebelumnya. Endapan

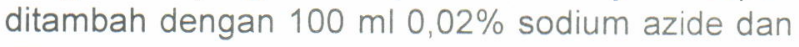
dihomogenisasikan selama 4 menit. Larutan yang diperoleh merupakan glikol kitin 1\% (b/v) (Trudel \& Aselin, 1980).

\section{Uji Daya Kitinolitik Kultur Bakteri}

Kultur yang digunakan dalam percobaan diuji terlebih dahulu daya kitinolitiknya menggunakan media sebagai berikut (Rahayu, 2000, dimodifikasi):

Koloidal kitin $2 \% ; \mathrm{K}_{2} \mathrm{HPO}_{4} \mathrm{O}, 1 \% ; \mathrm{MgSO}_{4} 7 \mathrm{H}_{2} \mathrm{O}$ $0,01 \%$; $\mathrm{NaCl} 3 \%$; Ammonium sulfat $0,7 \%$; Yeast ekstrak 0,05\%; Bakterial agar 2\%

Kultur bakteri Vibrio harveyi diinokulasikan dengan cara ditusukkan pada media padat dalam cawan petri, kemudian diinkubasikan pada $37^{\circ} \mathrm{C}$ selama 48 jam. Perbandingan diameter zona bening di sekeliling koloni (halo) dengan diameter koloni merupakan indeks kitinolitik.

\section{Optimasi Produksi Kitinase dan Kitin Deasetilase dari Vibrio harveyi}

Media starter dan media produksi yang digunakan adalah sebagai berikut (Rahayu, 2000, dimodifikasi):

Koloidal kitin 0,5\%; $\mathrm{K}_{2} \mathrm{HPO}_{4} 0,1 \% ; \mathrm{MgSO}_{4} 7 \mathrm{H}_{2} \mathrm{O}$ $0,01 \%$; $\mathrm{NaCl} 3 \%$; Ammonium sulfat $0,7 \%$; Yeast ekstrak 0,05\%, Trypton 0,1\%

Ke dalam 3 tabung yang berisi masing-masing 50 $\mu$ media starter pada $\mathrm{pH} 6,7$ dan 8 diinokulasikan masing-masing satu ose kultur bakteri dari media padat, kemudian diinkubasikan selama 24 jam pada suhu $37^{\circ} \mathrm{C}$. Setelah selesai masa inkubasi, media starter sebanyak $5 \mathrm{ml}$ diinokulasikan masing-masing 
ke dalam $150 \mathrm{ml}$ media produksi dengan $\mathrm{pH} \mathrm{6,7} \mathrm{dan}$ 8 , kemudian diinkubasikan pada suhu kamar, $37^{\circ} \mathrm{C}$ dan $47^{\circ} \mathrm{C}$ selama 5 hari. Setiap hari diambil sampel untuk dihitung jumlah bakterinya dan diukur aktivitas enzim kitin deasetilasenya. Aktivitas enzim kitinase diukur pada hari ke 5. Percobaan dilakukan menggunakan rancangan acak lengkap dengan tiga ulangan.

\section{Pengukuran Aktivitas Kitinase}

Aktivitas kitinase diukur menggunakan metode Wang dan Chang (1997) yang dimodifikasi. Persiapan sampel diawali dengan pembuatan larutan campuran yang terdiri atas campuran substrat kitin 1\% dengan larutan penyangga pH-7 dengan perbandingan 1:2. Untuk sampel, larutan campuran tersebut ditambah dengan larutan enzim sebanyak $1 / 3$ bagian dar jumlah larutan campuran, kemudian dikocok dengan vorteks dan diinkubasikan pada suhu $37^{\circ} \mathrm{C}$ selama 1 jam. Selesai inkubasi, larutan disentrifus pada suhu $4^{\circ} \mathrm{C}$, dengan kecepatan 8.000 rpm selama 10 menit. Filtrat disebut dengan larutan A. Untuk kontrol, larutan campuran antara substrat khitin dan penyangga (1:2) langsung dikocok dengan vorteks dan diinkubasikan pada suhu $37^{\circ} \mathrm{C}$ selama 1 jam. Setelah selesai inkubasi, ditambahkan larutan enzim sebanyak 1/3 bagian dari jumlah larutan campuran tersebut, yang disebut dengan larutan $B$.

Sampel adalah campuran yang tediri atas $500 \mu \mathrm{l}$ larutan A, $500 \mu$ lakuades dan $1.000 \mu$ reagen schale $(0,125 \mathrm{~g}$ K-ferrisianida dalam $250 \mathrm{ml} 0,5 \mathrm{M} \mathrm{Na}-$ karbonat), sedangkan kontrol adalah campuran yang terdiri atas $500 \mu$ larutan B, ditambah $500 \mu$ l akuades dan $1.000 \mu$ reagen schale. Adapun blanko dibuat dengan mencampur $1.000 \mu \mathrm{l}$ akuades dan $1.000 \mu \mathrm{l}$ reagen schale.

Selanjutnya terhadap ketiga campuran tersebut dilakukan pengukuran absorbansi dengan spektrofotometer pada panjang gelombang $420 \mathrm{~nm}$. Aktivitas kitinase ditentukan berdasarkan kurva standar $\mathrm{N}$-asetil glukosamin yang dibuat dengan mengukur absorbansi dari campuran antara larutan $\mathrm{N}$-asetil glukosamin (berkisar antara 0 hingga 500 $\mu \mathrm{l}$ ) dengan akuades (berkisar antara 500 hingga $0 \mu \mathrm{l}$ ) dan $500 \mu$ reagen schale pada panjang gelombang $420 \mathrm{~nm}$. Satu unit aktivitas enzim didefinisikan sebagai jumlah enzim yang menghasilkan $1 \mu \mathrm{mol} N$ asetil glukosamin per menit.

\section{Pengukuran Aktivitas Kitin Deasetilase}

Campuran antara $24 \mu \mathrm{l}$ glikol kitin 1\% dengan 136 $\mathrm{ml} 0,1 \mathrm{M}$ buffer borat $\mathrm{pH} 8$ dan $20 \mu \mathrm{l}$ enzim diinkubasikan 20 menit pada suhu $37^{\circ} \mathrm{C}$. Setelah selesai masa inkubasi, ke dalam campuran ditambahkan $200 \mu \mathrm{l}$ asam asetat 33\%. Hasil reaksi diambil $200 \mu \mathrm{l}$, ditambahkan $200 \mu \mathrm{Na}$-nitrit $5 \%$ dan $200 \mu \mathrm{l}$ asam asetat. Larutan dikocok dengan vorteks, dan dibiarkan 10 menit. Setelah itu, larutan campuran dikocok kembali dengan vorteks dan ditambah dengan $400 \mu$ amonium sulfamat $12,5 \%$ dan dideaminasi selama 30 menit sambil digoyang. Kemudian ditambah dengan $2 \mathrm{ml} \mathrm{HCl} 5 \%$ dan $400 \mu \mathrm{l}$ indol $1 \%$ dalam etanol Selanjutnya dimasukkan ke dalam air mendidih selama 5 menit, didinginkan, dan ditambah $800 \mu$ etanol absolut, dan dilakukan pengukuran absorbansi pada panjang gelombang $492 \mathrm{~nm}$. Untuk blanko, larutan enzim dimasukkan setelah penambahan $200 \mu \mathrm{l}$ asam asetat 33\%. Sebagai standar digunakan $200 \mu \mathrm{l}$ glukosamin dengan beberapa konsentrasi yang diperlakukan seperti contoh (Tokuyashu et al., 1996) Satu unit aktivitas enzim didefinisikan sebagai jumlah enzim yang menghasilkan $1 \mu \mathrm{mol}$ residu glukosamin per menit.

\section{HASIL DAN BAHASAN}

\section{Hasil Uji Daya Kitinolitik}

Vibrio harveyi mempunyai daya kitinolitik yang cukup tinggi karena lingkaran jernihnya yang cukup lebar, dengan indeks sekitar 3-5. Bakteri ini ternyata mempunyai daya kitinolitik yang hampir sama dengan Bacillus K29-14 yang berasal dari Kawah Kamojang Jawa Barat (Rahayu et al., 2000), yang bersifat termostabil dengan indeks kitinolitik sebesar 5,0 pada kondisi optimalnya, yakni pH 7 dengan suhu $55^{\circ} \mathrm{C}$.

\section{Optimasi Produksi Kitinase dan Kitin Deasetilase dari Vibrio harveyi}

\section{Jumlah bakteri}

Perkembangan jumlah bakteri selama produksi enzim adalah seperti pada Gambar 1

Perkembangan jumlah bakteri Vibrio harveyi uji selama produksi enzim ternyata tidak dipengaruhi oleh $\mathrm{pH}$ media, tetapi dipengaruhi oleh suhu inkubasi. Terlihat pada gambar tersebut bahwa pada suhu kamar $\left(28-31^{\circ} \mathrm{C}\right)$ bakteri sangat cepat melakukan adaptasi dari periode starter, sehingga mencapai $10^{\circ}$ dalam waktu 24 jam. Namun pada periode 4 hari berikutnya, jumlah bakteri tidak meningkat secara signifikan. Hal yang hampir sama terjadi pada suhu inkubasi $37^{\circ} \mathrm{C}$, meskipun pada suhu tersebut bakteri cenderung masih mengalami pertambahan jumlah hingga akhir pengamatan (5 hari). Pada suhu $47^{\circ} \mathrm{C}$, terlihat pola perkembangan bakteri yang berbeda. Masa adaptasi dilalui dengan lambat, sehingga jumlah bakteri tetap $10^{4}$ hingga satu hari inkubasi dalam media produksi enzim. Fase logaritmik baru tercapai setelah periode tersebut. Setelah itu, jumlah bakteri langsung masuk 


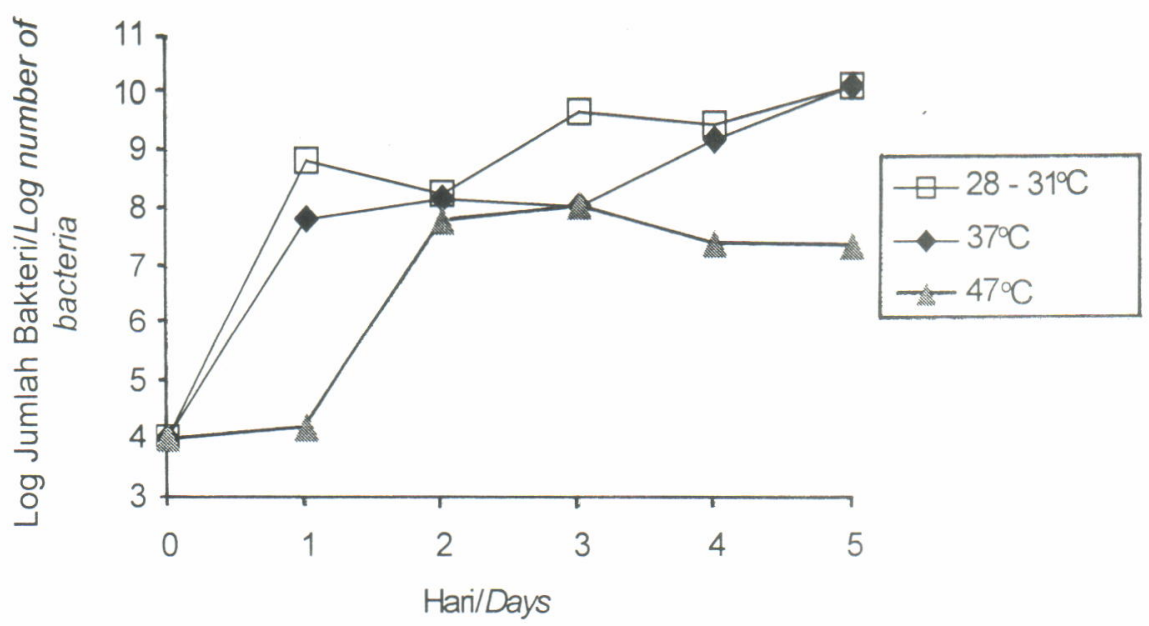

Gambar 1. Perkembangan jumlah bakteri Vibrio harveyi pada berbagai suhu inkubasi.

Figure 1. Changes of colony count of Vibrio harveyi during 5 days incubation at different temperatures.

ke fase konstan mengikuti pola kurva bakteri pada umumnya.

\section{Aktivitas kitinase}

Aktivitas enzim kitinase yang diproduksi oleh Vibrio harveyi setelah diinkubasikan selama 5 hari pada suhu dan $\mathrm{pH}$ yang berbeda adalah seperti pada Gambar 2
Seperti halnya dengan jumlah bakteri, aktivitas enzim kitinase yang diproduksi selama 5 hari inkubasi ternyata tidak dipengaruhi oleh $\mathrm{pH}$, dalam arti aktivitas optimumnya berkisar dari pH 6 hingga 8, dengan aktivitas rata-rata berkisar antara $6,98 \times 10^{-6}$ hingga $11,75 \times 10^{-6} \mathrm{u} / \mathrm{ml}$. Fenomena ini tidak banyak berbeda dengan hasil penelitian lain tentang kinerja kitinase yang dihasilkan oleh berbagai jenis bakteri. Rahayu

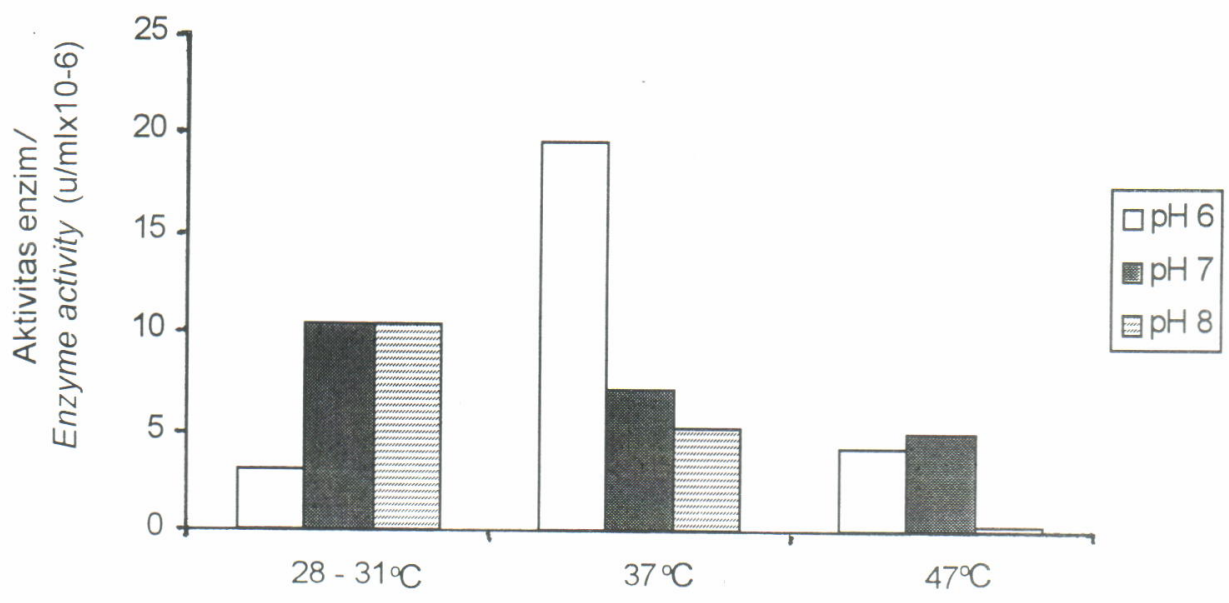

Suhu/Temperature

Gambar 2. Aktivitas enzim kitinase yang diproduksi oleh bakteri Vibrio harveyi setelah 5 hari inkubasi

Figure 2. Enzyme activity of chitinase produced by Vibrio harveyi after 5 days incubation. 
et al. (2000) menyatakan bahwa pH optimum kitinase yang dihasilkan oleh Bacillus K29-14 adalah 7. Pada $\mathrm{pH}$ optimum tersebut, aktivitas enzim pada $55^{\circ} \mathrm{C}$ mencapai 2,2 u/ml. Adapun tiga endokitinase termostabil dari Bacillus $\mathrm{MH}-1$ mempunyai $\mathrm{pH}$ optimum antara 5,5-6,5 (Sakai et al., 1998); dua kitinase yang dihasilkan oleh Streptomyces J13-3 mempunyai pH optimum 6,0 (Okazaki et al., 1995); sedangkan dua kitinase yang diproduksi oleh Pseudomonas aeruginosa $\mathrm{K}$-187 mempunyai kisaran $\mathrm{pH}$ yang luas yaitu masing-masing 6 hingga 9 dan 5 hingga 10 (Wang dan Chang, 1997).

Suhu inkubasi berpengaruh nyata, walaupun tidak terdapat perbedaan nyata antara inkubasi pada suhu $28-31^{\circ} \mathrm{C}$ dengan $37^{\circ} \mathrm{C}$ atau dengan $47^{\circ} \mathrm{C}$. Perbedaan nyata hanya terlihat antara suhu $37^{\circ} \mathrm{C}$ dengan $47^{\circ} \mathrm{C}$ dengan aktivitas yang lebih tinggi pada suhu $37^{\circ} \mathrm{C}$, yakni dengan nilai rata-rata mencapai $10,82 \times 10^{-6} \mathrm{u} /$ $\left(3,8 \times 10^{-5} \mathrm{u} / \mathrm{ml}\right)$, tetapi tidak berbeda dengan $\mathrm{pH} 8$ $\left(6,0 \times 10^{-5} \mathrm{u} / \mathrm{ml}\right)$. Walaupun demikian, ada interaksi antara $\mathrm{pH}$ dan suhu inkubasi serta antara ketiga faktor tersebut dalam mempengaruhi besarnya aktivitas enzim. Dari hasil ini dapat dikatakan bahwa aktivitas enzim tidak ditentukan oleh besaran jumlah se bakteri, tetapi lebih pada faktor kondisi lingkungan yaitu $\mathrm{pH}$. Bila dibandingkan dengan Bacillus K29-14 aktivitas ini belum cukup tinggi, karena pada kondisi optimumnya, Bacillus K29-14 dapat memproduksi kitin deasetilase dengan aktivitas mencapai 4,2 u/ml (Rahayu et al. ,2000)

\section{KESIMPULAN DAN SARAN}

Vibrio harveyi dapat memproduksi enzim kitinase dan kitin deasetilase yang ditunjukkan dari hasil uji daya kitinolitik, walaupun aktivitas enzim yang diperoleh masih rendah. Sama halnya dengan

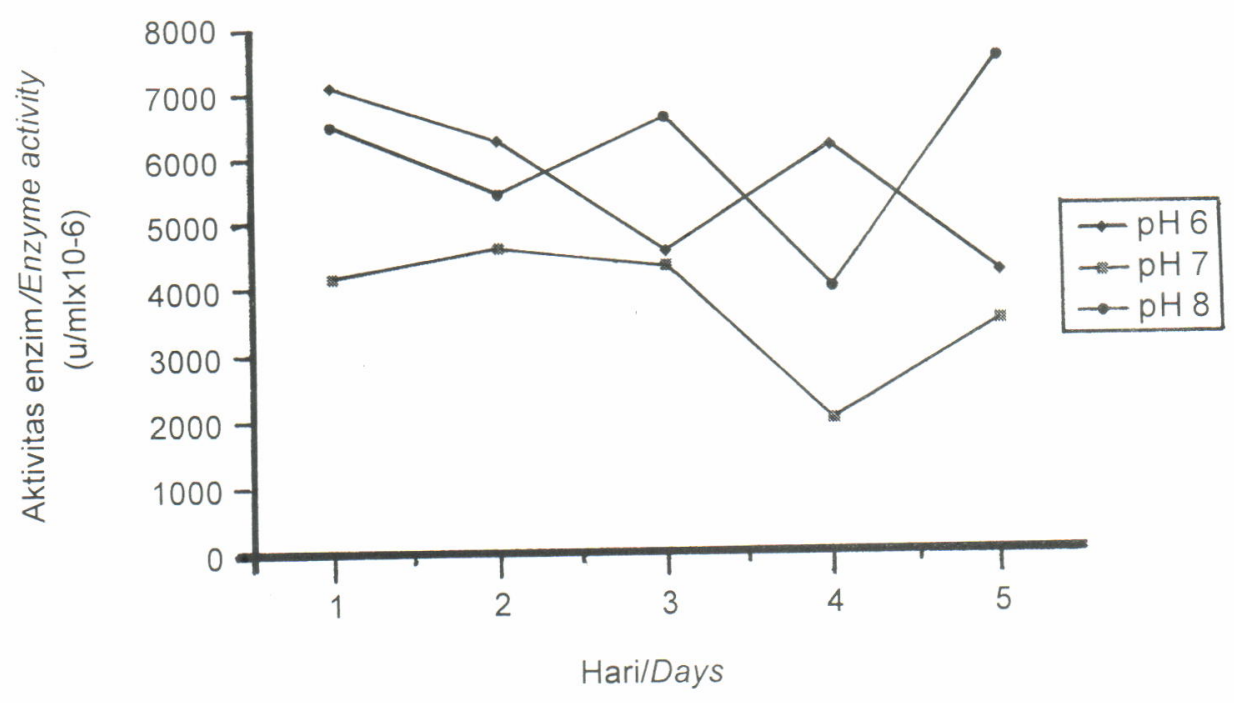

Gambar 3. Aktivitas enzim kitin deasetilase yang diproduksi oleh bakteri Vibrio harveyi pada pH yang berbeda. Figure 3. Enzyme activity of chitin deacetylase produced by Vibrio harveyi at different pHs.

$\mathrm{ml}$, dibandingkan dengan aktivitas pada $47^{\circ} \mathrm{C}$, yang nilai rata-ratanya hanya mencapai $3,56 \times 10^{-6} \mathrm{u} / \mathrm{ml}$.

\section{Aktivitas kitin deasetilase}

Aktivitas enzim kitin deasetilase yang diproduksi oleh Vibrio harveyi selama masa inkubasi pada $\mathrm{pH}$ yang berbeda adalah seperti pada Gambar 3.

Berbeda dengan perkembangan jumlah bakteri, aktivitas enzim kitin deasetilase ternyata justru dipengaruhi oleh $\mathrm{pH}$ media tetapi tidak oleh suhu dan waktu inkubasi. Aktivitas enzim rata-rata pada $\mathrm{pH} 6$ $\left(5,6 \times 10^{-5} \mathrm{u} / \mathrm{ml}\right)$ berbeda nyata dengan pada $\mathrm{pH} 7$ perkembangan jumlah bakteri selama masa produksi enzim, aktivitas enzim kitinase dipengaruhi oleh suhu inkubasi, tetapi tidak oleh $\mathrm{pH}$ media. Aktivitas ini mencapai rata-rata $10,82 \times 10^{-6} \mathrm{u} / \mathrm{ml}$ pada suhu $37^{\circ} \mathrm{C}$ dan $3,56 \times 10^{-6} \mathrm{u} / \mathrm{ml}$ pada suhu $47^{\circ} \mathrm{C}$. Sebaliknya, aktivitas enzim kitin deasetilase justru lebih dipengaruhi oleh $\mathrm{pH}$ media daripada suhu inkubasinya. Aktivitas rata-rata kitin deasetilase pada $\mathrm{pH} 6,7$, dan 8 berturut-turut adalah $5,6 \times 10^{-5} \mathrm{u} / \mathrm{ml} ; 3,8 \times 10^{-5} \mathrm{u} / \mathrm{ml}$, dan $6,0 \times 10^{-5} \mathrm{u} / \mathrm{ml}$

Untuk memanfaatkan kedua jenis enzim ini, tampaknya diperlukan upaya khusus, antara lain dengan perlakuan terhadap substrat misalnya dengan 
cara swelling terhadap substrat supaya mempermudah kerja enzim, maupun dengan pemurnian enzim.

\section{DAFTAR PUSTAKA}

Alam, Md. M., Mizutani, T., Isono, M., Nikaidou, N. and Watanabe,T. 1996. Three chitinase genes (chiA, chiB, and chiC) comprise the chitinase system of Bacillus circulans WL-12. J. Ferment Bioeng. 82(1): 28-36.

Alfonso,C., Neuro, O.M., Santamaria, F. and Reves, F. 1995. Purification of heat stable chitin deacetylase from Aspergillus nidulans and its role in cell wall degradation. J. Curr. Microbiol. 30(1): 49-54

Arnold, L.D. and Solomon, N.A. . 1986. Manual of Industrial Microbiology and Biotech. American Society for Microbiology, Washington.

Boucher, I, Dupuy, A., Vidal, P., Neugebauer, W.A. and Brzezinski, R. 1992. Purification and characterization of chitosanase from Streptomyces N-174. J. Appl. Microbiol. and Biotechnol. 38(2): 188-193

Bouriotis, V., Kafetzopoulos, D. and Vournakis, J. 1993. Process for isolating and preparing purified chitin deacetylase. Inst. Mol. Biol. Biotechnol. US Patent No. 5219749

Crawford D.L. and Mahadevan, B. 1997. Properties of the chitinase of the antifungal biocontrol agent Streptomyces lydicus WYEC-108. Enzyme Microb. Technol. 20(7): 489-493

Gao, X.D., Katsumoto, T., and Ondera, K. 1995. Purification and characterization of chitin deacetylase from Absidia coerulea. J. Biochem. 117(2): 257-263

Kafetzoupoulos,D., Martinou, A., Tsigos, I., Christodoulidou, A., Kavelaki, P. and Bouriotis, V. 1994. Chitin deacetylation by enzymic means. J. Prog. Biotechnol. 9(1): 291-294

Kirchman, D.L., Svitil, A.L., Chadain, S.M.N. and Moore, J.A. 1997. Chitin degradation proteins produced by the marine bacterium Vibrio harveyi growing in different form of chitin. J. Appl. Environ. Microbiol. 63(2): 408-413

Lindsay, G.J.H. and Gooday, G.W. 1985. Chitinolytic enzymes and the bacterial microflora in digestive tract of cod, Gadus morhua. J. Fish Biol. 26(3): 255-266

Martinou, A., Kafetzoupoulos, D. and Bouriotis, V. 1995. Chitin deacetylation by enzymatic means: monitoring of deacetylation process. J. Carbohydr. Res., 273(2): 235-242

Morikawa, Y., Nogawa, M., Takahashi, H., Kashigawa, A., Oshima, K. and Okada, H. 1998. Purification and characterization of exo-beta D-glucosaminidase from cellulotic fungus Trichoderma reesei PC-37. J. Appl. Environ. Microbiol., 64(3): 890-895

Okazaki, K., Kato, F., Watanabe, N. and Yusada, S. 1995. Purification and properties of two chitinases from Streptomyces J13-3. Bioschi. Biotech. Biochem. 59(8): 1586-1587

Ohishi, K., Yamagishi, M., Okta, T., Suzuki, M. and Izumida, H. 1996. Purification and properties of two chitinases from Vibrio alginolyticus $\mathrm{H}-8$. J. Ferment. Bioeng. 82(6): 598-600

Pelletier, A. and Sygusch, J.1990. Purification and characterization of three chitosanase activities from $\mathrm{Ba}$ cillus megaterium PI. J. Appl. Environ. Microbiol. 56(4): 844-848

Rahayu, S., Suhartono, M.T. dan Syah,D. 2000. Karakterisasi dan pemurnian kitinase dan kitin deasetilase termostabil dari isolat K29-14 asal Kawah Kamojang, Jawa Barat. Seminar Program Pasca Sarjana IPB.

Reves, F., Alfonso, C., Neuro, O.M. and Santamaria, F. 1995. Purification of heat-stable chitin deacetylase from Aspergillus nidulans and its role in cell wall degradation. Current Microbiol. 30(1): 49-54

Sakai, K., Yokota, A., Kurokawa, H., Wakayama, M. and Moriguchi, M. 1998. Purification and characterization of three thermostable endochitinases of a noble $\mathrm{Ba}$ cillus strain, $\mathrm{MH}-1$, isolated from chitin-containing compost. J. Appl. Environ. Microb. 64(9): 3397-3402

Saleh, M., Abdilah, R., Suherman, M., Basmal, J. dan Indriati, N. 1994. Pengaruh suhu, waktu, dan konsentrasi pelarut pada ekstraksi kitosan dari limbah pengolahan udang beku terhadap beberapa parameter mutu kitosan. Jurnal Pen. Pasca Panen Perikanan No.81:30-43

Sherief, A. A., El-Sawah, M.M., El-Naby, M. A. Abd. 1991. Some properties of chitinase produced by a potent Aspergillus carneus strain. J. Appl. Microbiol. Biotech. 35(2): 228-230

Svitil, A. L., Sinead, M., Chadhain, N. I., Moore, J. A. and Kirchman, D.L. 1996. Chitin degradation proteins produced by the marine bacterium Vibrio harveyi growing on different form of chitin. J. Appl. Environ. Microbiol. Feb.: 408-413

Tokuyashu, K., Kameyasa, M.O. and Hayashi, K. 1996. Purification and characterization of extracellular chitin deacetylase from Colletotricum lindemuthianum. Bioschi. Biochem. 60(10): 1598-1603

Trudel, J. and Aselin, A. 1980. Detection of chitinase activity after polyacrylamide gel electrophoresis. Analytical Biochem. 178: 362-366

Wang, San-Lang and Chang, Wen-Tsu, 1997. Purification and characterization of two bifunctional chitinases/lysozymes extracellularly produced by Pseudomonas aeruginosa $\mathrm{K}-187$ in a shrimp and crab shell powder medium. J. Appl. Environ. Microbiol. 63(2): 380-386

Wang, San-Lang and Chio, Sau-Hwa, 1998. Reversible immobilization of chitinase through coupling of reversibly soluble polymer. Enzyme Microb. Technol, 22(7): 634-640

Wang, San-Lang, Chang, Wen-Tsu, and Lu, M. C. 1995. Production of chitinase by Pseudomonas aeruginosa K-187 using shrimp and crab shell powder as a carbon source. Proc. of the National Science Council. Rep. of China, Part B: Life Sciences, 19(2): 105-112 